\author{
Oksana Yaremko, \\ PhD in Law, Associate Professor of the \\ Associate Professor of International Law and \\ Migration Policy, Western Ukrainian National \\ University \\ ORCID: https://orcid.org/0000-0002-6083-4379
}

\title{
«CANCEL CULTURE» AND CYBER-AGGRESSION: ISSUES OF LEGAL ASSESSMENT
}

Акцентовано увагу на актуальних питаннях безпечного і толерантного спілкування у глобальній інформаційній мережі «Інтернет». Досліджено зміст явища «сапсеl culture», його антиномічну природу і термінологічні особливості. Розкрито сутність «сапсеl culture» крізь призму правових иінностей (толерантність, справедливість, свобода слова, гуманність тощо). Проаналізовано проблемні аспекти відмежування «сапсеl culture» від форм кіберагресії (тролінг, хейт, кібербулінг, переслідування, кетколінг, шеймінг, блеймінг, флеймінг, гостінг, аутинг, квірбейтинг). Звернено увагу на проблемних аспектах юридичної відповідальності за деструктивну комунікацію у соиіальних мережах, у тому числі за зловживання під час «канцелінгу».

Ключові слова: «cancel culture», канцелінг, кіберактивності, кібербулінг, юридична відповідальність.

\section{Яремко О.}

"Cancel culture" и киберагресии: правовой аспект

В статье акиентировано внимание на актуальных вопросах безопасного и толерантного общения 6 глобальной информационной сети «Интернет». Исследовано содержание явления «сапсеl culturе», его антиномическую природу и терминологические особенности. Раскрыта сущңность «сапсеl сиіtuге» сквозь призму правовых иенностей (толерантность, справедливость, свобода слова, гуманность и т.п.). Проанализированы проблемные аспекты отграничения «cancel culture» от форм киберагресии (троллинг, хейт, кибербуллингу, преследования, кетколинг, шейминг, блейминг, флейминг, гостинг, аутинг, квирбейтинг). Обрамено внимание на проблемных аспектах юридической ответственности за деструктивную коммуникацию в социальных сетях, 8 том числе за злоупотребление во время «канцелингу».

Ключевые слова: «cancel culture», канцелинг, киберактивности, кибербуллинг, юридическая ответственность.

\section{Yaremko $O$.}

"Cancel culture» and cyber-aggression: issues of legal assessment

The article focuses on current safe and tolerant communication issues in the global information network «Internet». It is noted that society and Internet users are ambivalent about the phenomenon of «cancel culture». The content of this phenomenon and its terminological features are investigated. It is proposed to interpret «cancel culture» as a way to bring people or groups (famous or empowered) to justice for legal, social, ethical violations by refusing to support and (or) by public condemnation, mainly on social networks (unfollowing accounts, boycott of its projects). The essence of «cancel culture» is revealed through the prism of legal values (tolerance, justice, freedom of speech, humanity, etc.). Problematic aspects of distinguishing «culture» from forms of cyber aggression (trolling, hatred, cyberbullying, harassment, catcalling, shaming, blaming, flaming, hosting, outing, queerbaiting) are analyzed. It is noted that, unlike these forms of destructive communication on the Internet, "cell culture» is essentially a form of communication aimed at combating aggression, the struggle for justice, and, consequently, is a positive socio-cultural phenomenon. Attention is drawn to the problematic aspects of legal liability for destructive communication on social networks, including abuse during «cancelling».

Keywords: cancel culture, cancelling, cyber activities, cyberbullying, legal responsibility

Formulation of the problem. In the era of social networks, blogs and YouTube channels, «cancel culture» is becoming more widespread. The attitude to this phenomenon in society in general and among Internet users is ambiguous. Some interpret «cancel culture» («culture of abolition», «culture of exclusion», «canceling») as the practice of condemning or refusing to support a public figure because he, in the opinion of the public, has taken a problematic action or expressed an offensive opinion. Others are convinced that this phenomenon poses a threat to 
Yaremko $\mathrm{O}$.

«Cancel culture» and cyber-aggression: issues of legal assessment

society, as it is the «true activists» who suppress the free exchange of views, calling for a boycott and ostracizing ${ }^{1}$ people for statements they consider wrong and undesirable.

In recent years, a wave of «cancelling» has swept across all continents of the world. Gaining momentum, as well as the ambiguity of its perception, encourages modern society to think about a number of theoretical and legal issues, understanding the relationship, and sometimes competition, fundamental human rights and freedoms, the importance of lawmaking in relations where «cancel culture» develops (or relates to it).

Analysis of recent research and publications. In modern Ukrainian jurisprudence there is no thorough research on «cancel culture» and cyber-aggression. At the same time, some aspects of the problem we study are found in the works of Emily A. Vogels, Monica Anderson, Margaret Porteus, Chris Baronavski, Sara Atske, Colleen McClain, Brooke Auxier, Andrew Perrin, Meera Ramshankar [1], David Blixt [2], Tina Casey [3], Meredith Clark [4], Steven Mintz [5] and others.

The purpose of the article is to explore the issues of legal assessment of the «culture of abolition» and cyber-aggression.

Formulating the goals of the article. The main goals of this article are: 1) to study the contradictory nature of «cancel culture» and to reveal the meaning of this phenomenon through the prism of legal values; 2) to analyze the features of the phenomenon of «cancel culture» and point out its differences from the forms of cyber aggression; 3) to investigate the problems of legal liability in the light of «cancel culture» and cyber-aggression.

Presentation of the main research material. Before proceeding to the issues of legal assessment of «cancel culture», we consider it appropriate to dwell on the disclosure of the essence of this phenomenon and its terminological features.

The online encyclopedia «Wikipedia» states that cancel culture (or call-out culture) is a modern form of ostracism where someone is thrust out of social or professional circles whether it is online, on social media, or in person [6].

According to the Australian editors' Macquarie Dictionary, the phrase «cancel culture» became a word of $2019^{2}$ and it means a form of public condemnation, when in response to the actions of a person or brand, society boycotts it and ousts it. professional or social circles, as if «cancels» it [7].

Merriam Webster ${ }^{3}$ defines the term «cancel» as «the cessation of human support» [8]. And the online dictionary Dictionary.com defines the term as «termination of support («cancellation») of public figures and companies after they have done or said something that is considered outrageous or offensive» [9].

Usually, the persons, who are subjects to the act of «cancel culture», are public figures (politicians, entrepreneurs, musicians, bloggers, writers, journalists, actors, movie stars, influencers, comedians, fashion designers, etc.), for whom the number of their fans is archival both offline and online (electorate, customers, fans, subscribers, readers, viewers, etc.). Although sometimes the focus may be on an individual whose actions were recorded and found on the space of social networks.

The examples of famous people who have felt the effects of «cancel culture» are Joan Rowling, the writer (author of a series of novels about Harry Potter) - on charges of transphobia; American singer Lana Del Rey - on charges of anti-feminism; Jenna Marbles, a video blogger, - for using obscene language, gender stereotypes and black faces in her old videos [10]; Scarlett Johansson, an actress and a singer, - for agreeing to play the role of a transgender woman and others.

Well-known brands have repeatedly come under «cancelling». Especially those working in the fashion industry like Gucci - for Balaklava, who parodied caricatures of dark times of slavery; Dolce \& Gabbana - for advertising where an Asian model eats European food with chopsticks; Marc Jacobs and Comme des Garçons - for dreadlocks in white models; Virgil Ablo - for systematic plagiarism [11].

The consequences of «cancellation» include loss of friends and social connections, dismissal, lost business opportunities and deprivation of platforms to spread their views, sometimes really provocative.

«Cancellation» is closely linked to the concepts of «reputation» and «employment», according to New York Times columnist Ross Doutat. We can talk about real «cancelling» only when the audience demands the

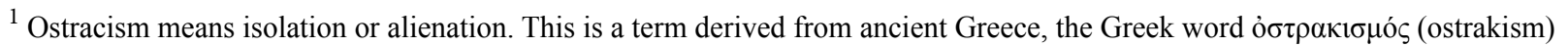
means expulsion by ostracism. Currently, in world politics, the term ostracism continues to be used when a member is removed because he does not like or in the interests of others. This member is called "persona no grata".

2 The Macquarie Dictionary is a dictionary in Australian English. Universities and lawyers usually consider it an authoritative source of Australian English. Each year, editors select a short list of new words to add to the dictionary and invite the public to vote for their favorite words. Public voting is held in January, the results of which determine the winner of the contest "People's Choice".

${ }^{3}$ Merriam Webster is an American company that publishes reference books and lexical dictionaries.
} 
release of a person whose behavior seemed offensive to them, and the termination of advertising contracts, refuses to «encourage money» in its activities [12]. In many cases, such «requirements» of the audience can force a person to take their words back. An example of a successful act of «cancel culture» is the «cancelling» in April 2021 of Regina Todorenko, a Russian influencer and a TV presenter, who said in an interview with PeopleTalk that women who are beaten by men should not talk about it publicly, but think about what their actions led to the beating by men [13].

The influencer>s audience reacted sharply to victim blaming, from Regina Todorenko>s transfer of responsibility for domestic violence to the victim. Glossy magazines deprived the influencer of the title of «Woman of the Year», and the brands «PepsiCo», «Pampers» refused to cooperate with her. As a result, in a week Regina Todorenko not only apologized, but also released a documentary on the problem of domestic violence, promising to direct all funds from monetization to help charitable foundations. The video garnered more than 4.2 million views on YouTube [14]. The story with Regina Todorenko is the story of Russia»s first act of «cancel culture», i.e. a public boycott of a person (and his activities), which broadcasts offensive and discriminatory views.

«Cancel culture» in social networks, as a complex socio-cultural phenomenon, is ambiguously perceived by modern society. The devaluation of this culture further stratified society into its supporters and opponents, contributed to a distorted understanding of the meaning of «cancel culture». Since the appearing, «canceling» has been considered a force capable of prosecuting celebrities for their contradictory behavior. Moreover, with the help of «cancel culture» users of social networks managed to start a dialogue in society about sexual violence in the media industry, which was previously silenced, and other, no less problematic issues, which were generally silenced. Due to the demand to «cancel» people began to express rejection of the point of view offensive to them and, thus, to change the cultural order, to form a legal culture in the social network, making certain things unacceptable. Previously, PR managers could keep any rumors in silence, domestic racism and sexism were considered the norm, and marginalized groups of people could not express their opinion to the general public. Now social networks have allowed users to speak out against influential people and «cancel culture» has made such protests visible.

Recently, however, the term «cancelling» has become somewhat questionable. It has come to be seen as a campaign of condemnation and harassment for beliefs or actions, even those committed in the past. We have witnessed when in English-speaking countries, under the slogans of the ideas of «cell culture», online harassment of historical figures for previously uttered insignificant phrases that are not popular in modern times (today to some extent sound somewhat discriminatory), which resulted in the overthrow of their monuments, renaming of streets and schools named after them, etc.

The devaluation of «cancel culture» is due to the distortion of its content and main purpose: not to bring the perpetrators to justice and to cover problematic issues, but simply to speculate on scandals and spread toxicity.

In order to create a safe Internet space, users of social networks must adhere to an online culture of communication, learn to correctly (legally) use media technology. However, according to Oksana Moroz, an expert in the field of media communication and culturology, there is no careful culture of communication in the online space [15]. She points to the existence of two currents of research into the causes of dysfunctional communication (cyber-aggression): the first - justifies the introduction of aggressive forms of communication from offline reality to online, and the second is the position that media technologies themselves provoke Internet users to abuse social networks misuse). Thus, Oksana Moroz notes that on the one hand, in the offline reality we face certain destructive forms of communication, including those related to the implementation of aggression. And they are quite easily transferred from offline to online, intensifying. And this intensification of more radical forms of dysfunctional ways of communication (cyber-aggression) is connected, first of all, with the fact that the Internet has long been a space of anonymized communication: a person could hide behind a certain identity, where he felt safer, implementing alternative its usual scenario activities.

On the other hand, as Oksana Moroz notes, when we talk about social media misuse, we ignore the idea of transferring behavior from offline to online. We emphasize that in the online environment, in digital platforms there are appropriate tools, certain functions and capabilities of platforms that make the expression of elements of dysfunctional communication more likely. We are not talking about the fact that there are certain cultural features that are transformed and broadcast from offline to online. And we claim that the tools of communication, tools of mass communication, social media, blogging platforms, updating the epistolary genre, e-mail services, etc., to some extent provoke types of dysfunctional communication (cyber-aggression) [16]. 
Yaremko $\mathrm{O}$.

«Cancel culture» and cyber-aggression: issues of legal assessment

Thus, the first direction of the study of cyber-aggression is based on the position that social practices have an impact on the use of technology, and the second - that technologies created by humans appropriately program social practices.

At the same time, the representatives of these two different positions distinguish approximately one «list» of dysfunctional communication practices (cyber-aggression): trolling, hate, cyberbulling, stalking, catcalling, shaming, blaming, flaming, ghosting, outing, queer baiting. Some of them include «cancel culture» in this list, i.e. consider it one of the forms of cyber aggression. In our opinion, this is not true. Although learning from the media about their alleged examples of acts of «office culture», we understand that in reality these are examples of trolling, hate, cyberbullying or other forms of Internet aggression. And they can not be described as examples of real acts of «cancel culture» (in the original sense). Here is one such example. In July 2020, Taylor Swift, an American singer and a songwriter, released a new folklore album. The singer s longplay ${ }^{4}$ was generally liked by critics. He was also praised by Pitchfork columnist Gillian Maps as she noted the good lyrics and indie sound of the release, but at the same time called it a bit mainstream ${ }^{5}$. Maps rated the album at 8 out of 10 , for which she received thousands of messages and calls with insults, ridicule and threats. Swift fans learned the address and phone number of the critic, posted edited personal photos, threatened to kill her and burn down the house. And although the harassment was not shared by all fans of the singer, the journalist had to close her social networks: «Surely afraid of people on the street and twitch during every phone call» [17].

Similar examples form a distorted understanding of «cell culture». And because of this, many people form the perception of «cell culture» as cyber-aggression. Therefore, in order to be able to give a correct assessment of one or another form of cyber-aggression and distinguish it from «cell culture», we will focus on revealing the content of the most common destructive behaviors on the Internet.

Let's start with trolling. Thus, trolling is a type of interaction in online discussions on virtual communication resources, when interaction is aimed at provoking readers' emotional response, emotional reaction, emotional arguments, insults and long useless discussions, flames, injecting conflicts to achieve the goals of Internet trolling. Internet troll violates the ethics of online interaction, established (accepted) communication practices, as well as demonstrates aggressive behavior. Internet trolls are chosen as a potential victim of those communities and groups that are perceived in the culture as vulnerable. Troll communication on the Internet can be compared to domestic rudeness.

Hatterism is the implementation of negative, aggressive, discriminatory statements about a particular person or phenomenon, which are not always accompanied by explicit motivation. Accordingly, hatred is a statement that in some way in a light form or devalues, or in a hard form demonstrates aggression against a person (very often are discriminatory). Shaming is an act of mortification. Blaming is the act of imposing guilt on a person who is most likely to be supported [18].

The report of the International Labor Organization «Safe and healthy working environments free from violence and harassment» (2020) clearly shows that cyberbullying, harassment and other forms of violence are quite common in all spheres of human activity. For example, in Canada, about $25 \%$ of the teaching staff of four schools reported being victims of cyberbullying: $15 \%$ of students were aggressors and $12 \%$ were colleagues.

In Brazil, a study of 269 physicians yielded the following results: 15\% of them faced physical violence, another 48\% - with psychological (verbal aggression), 25\% with «moral harassment». Patients were aggressors in $35.4 \%$ of cases, colleagues - in $25.3 \%$, managers - in $21.7 \%$ [19].

In Europe as a whole, $16 \%$ of workers (more often women than men) reported bullying, including cyberbullying (5\%). About 10\% of Australian workers have experienced bowling (cyberbullying) [20]. These statistics show that workers are almost vulnerable to cyberbullying or other forms of cyber activity.

In any of the above acts of communication (except, «cancel culture») there is an element of dysfunction, an element of aggression, an element of attack, and so on. «Cancel culture» is an alternative behavior to forms of cyber aggression. After all, if «stacking» and «cyberbullying» are undoubtedly not the best practices of communication with other people, then «cancelling» as a certain approach to explaining to large public figures, people with great social and cultural weight, capital, their wrongdoing (through the demonstration of dissatisfaction, which is carried out through the tools of the media or the Internet), is essentially a form of communication aimed at combating aggression, the struggle for justice, and therefore is a positive phenomenon [21].

\footnotetext{
${ }^{4}$ Longplay - a long-playing record

${ }^{5}$ Mainstream is a term that denotes the predominant direction in a certain field (scientific, cultural, media, etc.) for a certain period of time. It is often used to denote any "official", mass trends in culture, art, media to contrast with the alternative, underground, nonmass, elitist trends.
} 
Nowadays, public authorities do not pay due attention to the problem of «cancel culture» on the Internet as well as the problems associated with it. This is evidenced, first of all, by the lack of effective legislation that would solve the problem of legal liability of Internet users or companies that own social networks.

People who have been exposed to the acts of «cancel culture» in the Internet space often suffer from reputational losses. In the United States and Europe, everyone has long understood the importance of reputation: how it affects sales, recruitment and investment. For example, the UK Government's Competition and Markets Committee constantly refers to online reputation research. It is estimated that such damage costs businesses an average of 47 thousand pounds [22]. Persons subjected to «cancelling» experience certain moral suffering, anxiety for their honor and dignity. Accordingly, it is very important during «cancelling» to maintain a balance between the means of achieving the goal of «cancelling» and personal intangible rights aimed at individualization of the individual (the right to a name, the right to honor, dignity, business reputation, etc.). People should act within the framework of constitutional and civil law. They should make sure that the «cancelling» methods we use against discriminatory actions and statements do not themselves become discriminatory. In order to ensure justice, the Internet community does not endanger the right to freedom of speech, thought, action, religion, political preferences, etc. Also, the fear of being «cancelled», «banned» and the desire to please almost all users of social networks will provoke the formation of «insincerity» in communication, suppress the desire for self-realization and create «self-censorship». All this obliges the authorities to take proper care of the norms that provide for liability for violations of personal (non-property) human rights.

As we have already mentioned, «cancellation» is closely related to property, financial losses, lost profits, termination of contracts, loss of employment. It certainly requires the legislator to review the rules of economic and civil liability in order to comply with their new relationships that arise in the Internet space.

Meanwhile, the effect of cyber-aggression on a person is much more serious. This is evidenced by a study by Microsoft on the culture of communication and personal safety on the Internet, conducted in May 2019. The survey involved 12.5 thousand people - adolescents aged 13-17 years and adults 18-74 from 25 countries, including the United States, Canada, France, Germany, Great Britain, Poland, and Russia [23]. According to the results of the survey, 21 types of Internet threats were identified in four categories: behavioral, reputational, sexual threats and unwanted communications. We were interested in the fact that $45 \%$ of respondents experienced behavioral threats on the Internet (mostly rude behavior and trolling) and 21\% - reputational threats [24].

Both adult Internet users and adolescents claimed that they were most likely to encounter contempt on the Internet on social media. After all, two thirds of respondents said that they were subjected to abuse on social media pages, $24 \%$ - on media resources, $24 \%$ - on forums, $23 \%$ - on anonymous sites, $20 \%$ - on gaming sites [25].

Uncontrolled actions of opponents in the act of «cell culture», as well as opponents of the victim of cyberaggression, can lead to harm to mental or (and) physical health, to his death. Sometimes victims commit suicide. In these circumstances, it is important for law enforcement and the court to find out: what caused the suicide? Did the victim commit suicide because he was «cancelled» on a social network? Did «cancellation» transform into a form of cyber-aggression, such as signs of harassment that actually led the victim to suicide? There are other important issues for legal qualification. On the positive side, the criminal codes of modern states have special rules on criminal liability for leading to suicide through social networks (for example, Article 120 of the Criminal Code of Ukraine) [26].

People who are victims of all forms of violence, including harassment and intimidation, as well as cyberbullying, have the right to justice and to bring the offender to justice. Laws on criminal liability for harassment and bullying, especially for online harassment, are relatively new and have not yet been adopted in all countries. For this reason, in many countries, other laws related to insults and humiliation are used to punish offenders.

In the countries with special cyberbullying laws, other online behaviors that are aimed at causing the victim serious emotional distress are considered criminal acts. In some of these countries, victims of cyberbullying may seek protection, obtain a ban on the persecutor's communication with them, and temporarily or permanently restrict the persecutor's use of electronic devices used to carry out cyberbullying.

However, it is important to remember that punishment is not always the most effective way to correct offenders' behavior. We believe that the best thing is to focus on restorative justice methods: eliminating harm and reconciling the victim with the Internet offender.

Speaking of legal liability for destructive communication on the Internet, it is important not to forget about the liability of companies that own social networks. They are obliged to ensure the safety of their users. First of all, take care to protect children and youth. 
Yaremko $\mathrm{O}$.

«Cancel culture» and cyber-aggression: issues of legal assessment

It is well known that these companies (for example, Facebook / Instagram) have developed their own rules of communication within their social platforms. Facebook has a set of Community Standards, and Instagram has a Community Rules that they ask their users to follow. However, their security should not be limited to identifying content or accounts that violate these rules (for example, by harassment), review appeals (for erroneous removal of content). In our opinion, they are obliged to cooperate actively with law enforcement agencies in combating severe forms of cyber aggression. And criminal liability of technology companies for inaction in combating cyber aggression should be provided.

Recently, the question has arisen on the Internet: «Can technology corporations be responsible for suppressing freedom of speech, for reputational and other losses?» And it was ripe after Trump's accounts were «closed» by social networks. Even if we condemn Trump's actions, the decisions of Twitter and Facebook do raise questions about the need to regulate social networks. This example showed that the management of technology corporations (private companies), rather than the court, can actually take the mouthpiece from the US president [27]. This is a confirmation of the power of technology corporations - and vulnerabilities in the digital device of our society. Freedom of speech is the most important right, which can be limited only by law, and not in accordance with the decision of the management of social networks.

Conclusions. «Cancel culture» is a way to bring to justice for legal, social, ethical violations of a famous or empowered person or group by refusing support and (or) public condemnation, mainly on social networks (reply from acanthus, boycott of its projects). In practice, the devaluation of cancel culture is due to the distortion of its content and main purpose: not to bring the perpetrators to justice and to cover problematic issues, but simply to speculate on scandals and spread toxicity.

In contrast to such forms of destructive communication on the Internet as trolling, hate, cyberbulling, stalking, catcalling, shaming, blaming, flaming, ghosting, outing, queer baiting - «cancel culture» is in essence a form of communication aimed at combating aggression, the struggle for justice, and, consequently, is a positive phenomenon.

Laws on criminal liability for cyber-aggression are relatively new and have not yet been adopted in all countries. For this reason, many countries apply general insult and humiliation laws to punish offenders.

Technology corporations have a responsibility to ensure the safety of their users, especially children and young people.

\section{Список використаних джерел}

1. Americans and 'Cancel Culture': Where Some See Calls for Accountability, Others See Censorship, Punishment By Emily A. Vogels, Monica Anderson, Margaret Porteus, Chris Baronavski, Sara Atske, Colleen McClain, Brooke Auxier, Andrew Perrin and Meera Ramshankar. URL: https://www.pewresearch. org/internet/2021/05/19/americans-and-cancel-culture-where-some-see-calls-for-accountability-others-seecensorship-punishment/ (дата звернення: 26.06.2021).

2. David Blixt. «Cancel Culture» and Responsibility. URL: https://davidblixtauthor.medium.com/cancelculture-and-responsibility-b5b8065c3cbd (дата звернення: 26.06.2021).

3. Tina Casey. IBM Gets It Right on Cancel Culture and Corporate Responsibility URL: https://www.triplepundit. com/story/2021/ibm-cancel-culture/717576 (дата звернення: 26.06.2021).

4. Meredith Clark. The powerful blame «cancel culture» to deflectresponsibility. URL: https://democracyinitiative. virginia.edu/news/story/powerful-blame-cancel-culture-deflect-responsibility (дата звернення: 26.06.2021).

5. Steven Mintz. Cancel Culture: A Variety of Perspectives. URL: https:/www.ethicssage.com/2021/05/cancelculture-a-variety-of-perspectives.html

6. Cancel culture. URL: https://en.wikipedia.org/wiki/Cancel_culture (дата звернення: 26.06.2021).

7. Морі Євгеній. Що таке cancel culture та як люди знову опинилися по різні боки барикад. URL: https:// suspilne.media/48015-so-take-cancel-culture-ta-ak-ludi-znovu-opinilisa-po-rizni-boki-barikad/ (дата звернення: 26.06.2021).

8. Merriam Webster. URL: https://www.merriam-webster.com/dictionary/cancel?src=search-dict-box (дата звернення: 26.06.2021)

9. Dictionary.com URL: https://www.dictionary.com/browse/cancel (дата звернення: 26.06.2021).

10. Cancel culture. URL: https://en.wikipedia.org/wiki/Cancel_culture (дата звернення: 26.06.2021).

11. Мажар Андрей. Все друг друга ненавидят: что такое cancel culture и чего от нее больше - вреда или пользы. URL: https://donttakefake.com/vse-drug-druga-otmenyayut-chto-takoe-cancel-culture-i-chego-otnee-bolshe-vreda-ili-polzy/ (дата звернення: 26.06.2021). 
12. Культура отмены: как интернет следит за вашей репутацией. URL: https://aily.afisha.ru/brain/17861kultura-otmeny-kak-internet-sledit-za-vashey-reputaciey/ (дата звернення: 26.06.2021).

13. Культура отмены: как интернет следит за вашей репутацией. URL: https://daily.afisha.ru/brain/17861kultura-otmeny-kak-internet-sledit-za-vashey-reputaciey/ (дата звернення: 26.06.2021).

14. Культура отмены: как интернет следит за вашей репутацией. URL: https://aily.afisha.ru/brain/17861kultura-otmeny-kak-internet-sledit-za-v ashey-reputaciey/ (дата звернення: 26.06.2021).

15. Семинар «От буллинга до cancel culture: противоречия «бережной культуры общения». URL: https:// www.youtube.com/watch?v=I-VxlOlW5aA (дата звернення: 26.06.2021).

16. Семинар «От буллинга до cancel culture: противоречия «бережной культуры общения». URL: https:// www.youtube.com/watch?v=I-VxlOlW5aA (дата звернення: 26.06.2021).

17. Мажар Андрей. Все друг друга ненавидят: что такое cancel culture и чего от нее больше - вреда или пользы. URL: https://donttakefake.com/vse-drug-druga-otmenyayut-chto-takoe-cancel-culture-i-chego-otnee-bolshe-vreda-ili-polzy/ (дата звернення: 26.06.2021).

18. Семинар «От буллинга до cancel culture: противоречия «бережной культуры общения». URL: https:// www.youtube.com/watch? $\mathrm{v}=\mathrm{I}-\mathrm{VxlOlW5aA}$ (дата звернення: 26.06.2021).

19. Семинар «От буллинга до cancel culture: противоречия «бережной культуры общения». URL: https:// www.youtube.com/watch?v=I-VxlOlW5aA (дата звернення: 26.06.2021).

20. Семинар «От буллинга до cancel culture: противоречия «бережной культуры общения». URL: https:// www.youtube.com/watch?v=I-VxlOlW5aA (дата звернення: 26.06.2021).

21. Семинар «От буллинга до cancel culture: противоречия «бережной культуры общения». URL: https:// www.youtube.com/watch?v=I-VxlOlW5aA (дата звернення: 26.06.2021).

22. Семинар «От буллинга до cancel culture: противоречия «бережной культуры общения». URL: https:// www.youtube.com/watch?v=I-VxlOlW5aA (дата звернення: 26.06.2021).

23. Культура спілкування в інтернеті впала до найнижчого рівня за чотири роки - Microsoft. URL: https://imi.org.ua/news/kultura-spilkuvannya-v-interneti-vpala-do-najnyzhchogo-rivnya-za-chotyry-rokymicrosoft-i31691 (дата звернення: 26.06.2021).

24. Культура отмены: как интернет следит за вашей репутацией. URL: https://aily.afisha.ru/brain/17861kultura-otmeny-kak-internet-sledit-za-vashey-reputaciey/ (дата звернення: 26.06.2021).

25. Культура спілкування в інтернеті впала до найнижчого рівня за чотири роки - Microsoft. URL: https://imi.org.ua/news/kultura-spilkuvannya-v-interneti-vpala-do-najnyzhchogo-rivnya-za-chotyry-rokymicrosoft-i31691 (дата звернення: 26.06.2021).

26. Criminal Code of Ukraine. URL: https://zakon.rada.gov.ua/laws/show/2341-14?lang=en\#Text (дата звернення: 26.06.2021).

27. Трамп без «Твиттера»: цензура или защита демократии? URL: https://www.bbc.com/russian/ features-55625897 (дата звернення: 26.06.2021).

\section{References}

1. Emily A. Vogels, Monica Anderson, Margaret Porteus, Chris Baronavski, Sara Atske, Colleen McClain, Brooke Auxier, Andrew Perrin, Meera Ramshankar. Americans and 'Cancel Culture': Where Some See Calls for Accountability, Others See Censorship, Punishment. Retrieved from https://www.pewresearch. org/internet/2021/05/19/americans-and-cancel-culture-where-some-see-calls-for-accountability-others-seecensorship-punishment/ (accessed 26 June 2021).

2. David Blixt. «Cancel Culture» and Responsibility. Retrieved from https://davidblixtauthor.medium.com/ cancel-culture-and-responsibility-b5b8065c3cbd (accessed 26 June 2021).

3. Tina Casey. IBM Gets It Right on Cancel Culture and Corporate Responsibility. Retrieved from https://www. triplepundit.com/story/2021/ibm-cancel-culture/717576 (accessed 26 June 2021).

4. Meredith Clark. The powerful blame «cancel culture» to deflect responsibility. Retrieved from https:// democracyinitiative.virginia.edu/news/story/powerful-blame-cancel-culture-deflect-responsibility (accessed 26 June 2021).

5. Steven Mintz. Cancel Culture:A Variety of Perspectives. Retrieved from: https://www.ethicssage.com/2021/05/ cancel-culture-a-variety-of-perspectives.html (accessed 26 June 2021).

6. Cancel culture. Retrieved from: https://en.wikipedia.org/wiki/Cancel_culture (accessed 26 June 2021).

7. Mori Evgenei. Shcho take «cancel culture» ta iak liudy znovu opynylysia po rezne boky barykad [What is cancel culture and how people found themselves on different sides of the barricades again]. Retrieved 
Yaremko O.

«Cancel culture» and cyber-aggression: issues of legal assessment

from: https://suspilne.media/48015-so-take-cancel-culture-ta-ak-ludi-znovu-opinilisa-po-rizni-boki-barikad/ (accessed 26 June 2021).

8. Merriam Webster. Retrieved from: https://www.merriam-webster.com/dictionary/cancel?src=search-dict-box (accessed 26 June 2021).

9. Dictionary.com. Retrieved from: https://www.dictionary.com/browse/cancel (accessed 26 June 2021).

10. Cancel culture. Retrieved from: https://en.wikipedia.org/wiki/Cancel_culture (accessed 26 June 2021).

11. Mazhor Andrei. Vse drug druga nenavediat: chto takoie «cancel culture» i chego ot neie bol'she - vreda ili pol'zy [Everyone hates each other: what is cancel culture and what is more from it - harm or benefit]. Retrieved from: https://donttakefake.com/vse-drug-druga-otmenyayut-chto-takoe-cancel-culture-i-chego-otnee-bolshe-vreda-ili-polzy/ (accessed 26 June 2021).

12. Kul'tura otmeny: kak internet sledit za vashei reputatsiei [Cancellation culture: how the internet monitors your reputation]. Retrieved from: https://daily.afisha.ru/brain/17861-kultura-otmeny-kak-internet-sledit-zavashey-reputaciey/ (accessed 26 June 2021).

13. Kul'tura otmeny: kak internet sledit za vashei reputatsiei [Cancellation culture: how the internet monitors your reputation]. Retrieved from: https://daily.afisha.ru/brain/17861-kultura-otmeny-kak-internet-sledit-zavashey-reputaciey/ (accessed 26 June 2021).

14. Kul'tura otmeny: kak internet sledit za vashei reputatsiei [Cancellation culture: how the internet monitors your reputation]. Retrieved from: https://daily.afisha.ru/brain/17861-kultura-otmeny-kak-internet-sledit-za-v ashey-reputaciey/ (accessed 26 June 2021).

15. Seminar «Ot bulling do cancel culture: «berezhnoi kul'tury obshchenie» [Seminar «From bullying to cancel culture: the contradictions of the «careful culture of communication»]. Retrieved from: https://www.youtube. com/watch? $\mathrm{v}=\mathrm{I}-\mathrm{Vx}$ xlOlW5aA (accessed 26 June 2021).

16. Seminar «Ot bulling do cancel culture: «berezhnoi kul'tury obshchenie» [Seminar «From bullying to cancel culture: the contradictions of the «careful culture of communication»]. Retrieved from: https://www.youtube. com/watch? $=I-V x 1 O l W 5 a A$ (accessed 26 June 2021).

17. Mazhor Andrei. Vse drug druga nenavediat: chto takoie «cancel culture» i chego ot neie bol'she - vreda ili pol'zy [Everyone hates each other: what is cancel culture and what is more from it - harm or benefit]. Retrieved from: https://donttakefake.com/vse-drug-druga-otmenyayut-chto-takoe-cancel-culture-i-chego-otnee-bolshe-vreda-ili-polzy/ (accessed 26 June 2021).

18. Seminar «Ot bulling do cancel culture: «berezhnoi kul'tury obshchenie» [Seminar «From bullying to cancel culture: the contradictions of the «careful culture of communication». Retrieved from: https://www.youtube. $\mathrm{com} /$ watch? $\mathrm{v}=\mathrm{I}-\mathrm{VxlOlW} 5 \mathrm{aA}$ (accessed 26 June 2021).

19. Seminar «Ot bulling do cancel culture: «berezhnoi kul'tury obshchenie» [Seminar «From bullying to cancel culture: the contradictions of the «careful culture of communication». Retrieved from: https://www.youtube. $\mathrm{com} /$ watch? $\mathrm{v}=\mathrm{I}-\mathrm{Vx}$ xlOlW5aA (accessed 26 June 2021).

20. Seminar «Ot bulling do cancel culture: «berezhnoi kul'tury obshchenie» [Seminar «From bullying to cancel culture: the contradictions of the «careful culture of communication». Retrieved from: https://www.youtube. $\mathrm{com} /$ watch? $\mathrm{v}=\mathrm{I}-\mathrm{Vx}$ IOlW5aA (accessed 26 June 2021).

21. Seminar «Ot bulling do cancel culture: «berezhnoi kul'tury obshchenie» [Seminar «From bullying to cancel culture: the contradictions of the «careful culture of communication». Retrieved from: https://www.youtube. $\mathrm{com} /$ watch? $\mathrm{v}=\mathrm{I}-\mathrm{Vx}$ IOlW5aA (accessed 26 June 2021).

22. Seminar «Ot bulling do cancel culture: «berezhnoi kul'tury obshchenie» [Seminar «From bullying to cancel culture: the contradictions of the «careful culture of communication». Retrieved from: https://www.youtube. $\mathrm{com} /$ watch? $\mathrm{v}=\mathrm{I}-\mathrm{VxlOlW} 5 \mathrm{aA}$ (accessed 26 June 2021).

23. Kul'tura spilkuvannia $\mathrm{v}$ internet vpala do nainyzhchogo rivnia za chotyry roky - Microsoft [The culture of communication on the Internet has fallen to its lowest level in four years - Microsoft]. Retrieved from: https://imi.org.ua/news/kultura-spilkuvannya-v-interneti-vpala-do-najnyzhchogo-rivnya-za-chotyry-rokymicrosoft-i31691 (accessed 26 June 2021).

24. Kul'tura otmeny: kak internet sledit za vashei reputatsiei [Cancellation culture: how the internet monitors your reputation]. Retrieved from: https://daily.afisha.ru/brain/17861-kultura-otmeny-kak-internet-sledit-zavashey-reputaciey/ (accessed 26 June 2021).

25. Kul'tura spilkuvannia $v$ internet vpala do nainyzhchogo rivnia za chotyry roky - Microsoft [The culture of communication on the Internet has fallen to its lowest level in four years - Microsoft]. Retrieved from: 
https://imi.org.ua/news/kultura-spilkuvannya-v-interneti-vpala-do-najnyzhchogo-rivnya-za-chotyry-rokymicrosoft-i31691 (accessed 26 June 2021).

26. Criminal Code of Ukraine. Retrieved from: https://zakon.rada.gov.ua/laws/show/2341-14?lang=en\#Text (accessed 26 June 2021).

27. Tramp bez «Tvittera»: tsenzura ili zashchita demokratii [Trump without Twitter: Censorship or the Defense of Democracy?]. Retrieved from: https:/www.bbc.com/russian/features-55625897 (accessed 26 June 2021). 